\title{
The Effect of Pregnancy on Pepsinogen Secretion and its Possible Role in Protection of Peptic Ulcer Disease
}

M. Mujahid Ali, Ph.D., C. M. Habibullah, M.D. D.M., Nayana Joshi, Ph.D., and Arshiya Nasreen M.Sc., Hyderabad, (A.P.), India

DOI: http://dx.doi.org/10.5915/21-2-13310

\begin{abstract}
This study is aimed to see the effect of pregnancy on pepsinogen secretion and its possible protective role against ulceration. Fifty pregnant women without symptoms of peptic ulcer disease were studied for serum pepsinogen level. These levels were compared with those of a control group composed of age-matched, nonpregnant healthy women. An elevated level of serum pepsinogen was found during pregnancy. Fourteen percent of pregnant women had low levels of pepsinogen while $20 \%$ showed normal pepsinogen level, because they were associated with severe anemia. Regular feeding, good nutrition, and emotional tranquility during pregnancy were favourable factors to reduce the chances of ulceration. Increased secretion of estrogen and progesterone, increased secretion of gastric mucus, bicarbonate and prostaglandins during pregnancy enhance cytoprotection against ulceration. Increased secretion of histaminase blocks or destroys the histamine action at the parietal cells which slows down acid secretion and helps to avoid ulcer formation.
\end{abstract}

Key words: Pregnancy, pepsinogen, peptic ulcer.

Several factors such as blood group $O$, smoking, and stress have been shown to have an effect on gastric secretion of both acid and pepsin..$^{1-3}$ Gastric secretion has also been shown to be altered in some disease conditions.", Very few reports are available to show gastric acid and pepsinogen secretions during pregnancy. ', ' This study was carried out to examine the effect of pregnancy on serum pepsinogen levels and to explore the reasons why females are less susceptible to peptic ulcers during pregnancy.

\section{Materials and methods}

Fifty pregnant women between 17 and 31 years of

From the Department of Gastroenterology Osmania General Hospital

Hyderabad (A.P.), India

Reprint Requests: Dr. M. Mujahid Ali

Department of Gastroenterology

Osmania General Hospital

Hyderabad (A.P.), India age (mean age $23.6 \pm 3.1$ ) without symptoms or past medical history of peptic ulcer disease were selected for this study. Thirty non-pregnant healthy women within the same age group were also studied as controls. Pregnancy was confirmed by ultrasound and/or other specific tests. Cases were selected from the Government Maternity Hospital, Hyderabad. Pepsinogen studies were conducted in the Department of Gestroenterology, Osmania General Hospital, Hyderabad. Eighteen of the pregnant women were in the second trimester while 32 were in the third trimester. A detailed antenatal checkup was done in each case. There were 15 primigravid and 35 multigravidae women in the study.

Blood samples were collected during routine checkups and serum pepsinogen levels were estimated by the method of Mirsky et al using hemoglobin as a substrate. Statistical analysis was carried out by using Student " $t$ " test.

Results

The mean serum pepsinogen level for pregnant women was $856.0 \pm 474.1$ units $/ \mathrm{ml} / 24 \mathrm{~h}$ (mean \pm 


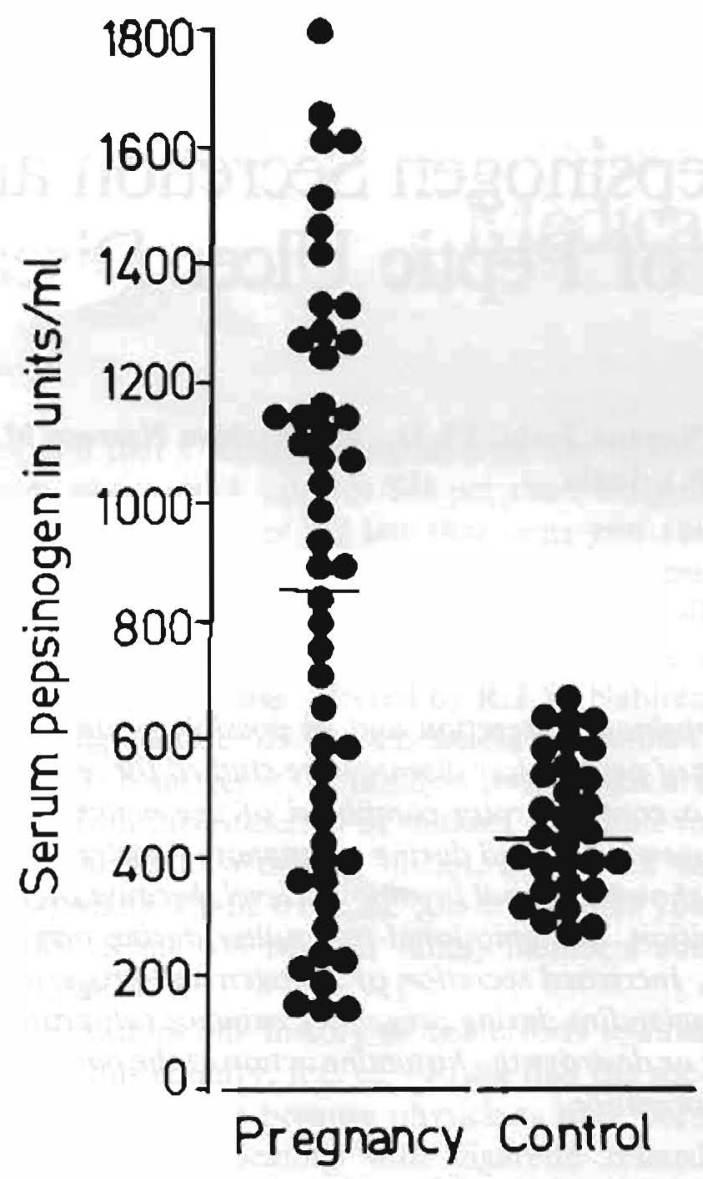

Figure: Distribution of serum pepsinogen levels in pregnant women and healthy controls.

$\mathrm{SD})$, whereas in the non-prgnant controls it was $435.6 \pm 96.2$ units $/ \mathrm{ml} / 24 \mathrm{~h}$. (Figure) The difference between the mean value of pepsinogen in pregnant and non-pregnant females was statistically significant (P60.001). During the second trimester of pregnancy, the mean level of pepsinogen was $736.2 \pm 408.7$ units $/ \mathrm{ml} / 24 \mathrm{~h}$, whereas in the third trimester of pregnancy it was $923.3 \pm 500.7$ units $/ \mathrm{ml} / 24 \mathrm{~h}$. In both periods, the mean serum pepsinogen value was significantly elevated when compared with the mean value in non-pregnant controls. However, the difference between third and second trimester pepsinogen levels was not statistically significant. Mean serum pepsinogen levels of primigravidae were $950.5 \pm 350.9$ units $/ \mathrm{ml} / 24 \mathrm{~h}$, and in multigravidae it was $816.4 \pm 515.8$ units $/ \mathrm{ml} / 24 \mathrm{~h}$. The difference between these two values was also not statistically significant. Seven pregnant women (3 second trimester and 4 third trimester) had low pepsinogen values (mean $162.3 \pm 75.7$ units $/ \mathrm{ml} / 24 \mathrm{~h}$ ), while ten pregnant women had normal pepsinogen levels (mean $=473.5 \pm 109.7$ units $/ \mathrm{ml} / 24 \mathrm{~h}$ ).

\section{Discussion}

An increased serum pepsinogen level was found in $66 \%$ of the pregnant women studied. Similar findings were reported by others; ${ }^{6}$ however, Waldrum et al $^{9}$ reported that pepsinogen levels were not significantly increased in pregnant compared to control women. The latter investigators, using a radioimmunoassy method, measured the levels of only group-I pepsinogen while this study and Gryboski et $\mathrm{al}^{6}$ measured total pepsinogen groups I and II, and also used the same hemoglobin substrate method." Is may be that the increase is mainly in the group 11 pepsinogen fraction. Estrogen and progesterone levels are known to be increased during pregnancy. ${ }^{10} \mathrm{We}$ postulate that these hormones act on the chief gastric cells stimulating the production of pepsinogen.

We have previously reported a direct correlation between gastric acid secretion and serum pepsinogen levels as well as a correlation between parietal cell and chief cell masses. ${ }^{*}$ Our finding of increased pepsinogen levels in association with reduced gastric secretion in pregnancy seems to be peculiar to the pregnant state. It is probably the result of the production of histaminase by the placenta. Histaminase blocks or destroys acid secretion but does not have any effect on chief cells or on pepsinogen secretion. ${ }^{14}$

Twenty percent of our study population had normal pepsinogen levels and only $14 \%$ had reduced levels. Women having reduced levels belonged to economically poor families, and each had severe anemia $(9 \mathrm{G} / \mathrm{dl})$. Their poor health and anemic condition might have contributed to the low level of pepsinogen. There are some reports that have shown that with anemia, serum pepsinogen levels drop. ${ }^{12,13}$

Females are less susceptible to peptic ulcer disease than males. ${ }^{14}$, is The risk of developing peptic ulcer during pregnancy is further reduced. Indeed, the protective effect of pregnancy may be one of the major factors that lowers the incidence of peptic ulcer disease in women. During pregnancy, women give more attention to regular feeding, good nutrition, and are usually under less stress. During this period, women also generally avoid or reduce their use of medications, particularly aspirin, which is one of the ulcer causing agents.

Several mechanisms have been proposed to explain the protective effect of pregnancy. Increased gastric and duodenal mucus secretion, possibly the effect of increased estrogen levels, ${ }^{16,17}$ delayed gastric emptying secondary to increased progesterone secretion, " and decreased gastric acid secretion ${ }^{6}$ are the most important suggested mechanisms. While the cause of decreased gastric acid secretion in pregnancy is not clear, it has been postulated to be due to increased levels of estrogen and progestgerone. However, another mechanism may be that placental histaminase may block or destroy the action of histamine at the parietal cells causing a decrease in 
their acid secretion." In addition, placental gastrotrophic factors and increased prostaglandin production may have cyto-protective effects on the gastric mucosa. ${ }^{17,18}$ These factors have been postulated to act by strengthening of the gastric mucosal barrier with a reduction in hydrogen ion back diffusion, ${ }^{19}$ by increasing gastric and duodenal mucus secretion, ${ }^{20}$ by increasing gastric and duodenal bicarbonate, ${ }^{21}$ and by increasing mucosal blood flow. ${ }^{22,23}$

While our finding of increased pepsinogen levels during pregnancy may seem to interfere with the known protective effect of pregnancy, it is not so. Both gastric acid and pepsinogen are necessary for ulcer development. With absent or reduced levels of gastric acid, the gradual, slight and time limited increase in pepsinogen secretion does not favor the development of peptic ulcers, particularly while the other protective mechanisims outlined above are operative, as during pregnancy.

\section{Reference}

1. Hanley WB: Hereditary aspects of duodenal ulceration. Br Med J 1964; 1:936-940.

2. Piper DW, and Raine JM: Effect of cigarette smoking on gastric secretion. Lancet 1959; 1:696-698.

3. Walker, Luther, J, Samloff M, and Feldman M: Life events stres and psychosocial factors in men with peptic ulcer disease. II. Relation with serum pepsinogen concentration and behavioral risk factors. Gastroenterology 1988; 94:323-330.

4. Mujahid Ali M, Habibullah $\mathrm{CM}$, Ishaq $\mathrm{M}$, and Saleem Y: A study of the relationship between gastric acid secretion and total serum pepsinogen levels in duodenal ulcer. Trop Gastroentrol 1986; 7:62-64.

5. Habibullah C, Mujahid Ali M, Jayanthi M, and Hasan Ali: Serum pepsinogen levels in patients with carcinoma of stomach. Ind J Gastroentrol 1987; 6:171-172.

6. Gryboski WA, and Spiro HM: The effect of pregnancy on gastric secretion. New Engl J Med 1956; 255:1131-1134.

7. Murray FA, Erskine JP, Fielding J: Gastric Secretion in Pregnancy. J Obstet Gynaecol Br Commonw 1957; 64:373-375.

8. Mirsky IA, Futherman P, and Kaplan S, et al: Blood plasma pepsinogen. J Lab Clin Med 1952;
40:17-26.

9. Waldrum HL, Straanme BK, Lundgren R: Serum pepsinogen I during pregnancy. Scand J Gastroenterol 1980; 15:61-65.

10. Vanthiel DH, Gavaler JS, Joshi SN, et al: Heartburn in pregnancy. Gastroenterelogy 1977; 72:66-668.

11. Clark DH, Tankel HI: Gastric acid and plasma histaminase during pregnancy. Lancet 1954; 2:886-887.

12. Attken MA, Spray GH, and Walter G: Gastric pepsin and the excretion of uropepsinogen in anaemia Clin Sci 1954; 13:119-126.

13. Hirschowitz BI: Pepsinogen. Postgrad Med J 1984; 60:743-750.

14. Malhotra SL: Peptic ulcer in India and its aetiology. Gut 1964; 5:412-416.

15. Tovey Fl. Peptic ulcer in India and Bangladesh. Gut 1979;

16. Kaufmann HJ, Spiro HM: Estrogen and gastric secretion. Gastroenterology 1968; 54:913-917.

17. Rustgi VK, Cooper JN: Gastrointestinal and hepatic complications in pregnancy. USA: John Wiley \& Sons, Inc., 1986; 87-103.

18. Homberg M: Quantitative studies on prostaglandins synthesis in man. III. Excretion of the major urinary metabolite of PGF1 and PGF2 during pregnancy. Life Science 1974; 14:247-252.

19. Chaudhury TK, Jacobson ED: Prostaglandin cytoprotection of gastric mucosa. Gastroenterology 1978; 74:58-63.

20. Wilson DE, Levendoglu $\mathrm{H}$, Adams A, et al: $A$ new PGE analogue (CL 115, 574) III. Effects on gastric acid and mucus secretion in man. Prostaglandins 1984; 28:5-11.

21. Selling JA, Hogan DL, Koss MA, et al: Human proximal versus distal duodenal bicarbonate secretion: Effect of endogenous prostaglandin synthesis. Gastroenterology 1985; 88A: 1580.

22. Calton DG, Driskill DR, Phillips ER, et al: Effect of SC-29333, an inhibitor of gastric mucosal blood flow and serum gastrin levels. Arch Int Pharmacodyn 1978; 236:86-95.

23. Leung FW, Itoh M, Hirabayashik, et al: Role of blood flow in gastric and duodenal mucosal injury in the rat. Gastroenterology 1985; 88:281-289. 